Article

\title{
The Australian Royal Commission into Institutional Responses to Child Sexual Abuse: Dreaming of Child Safe Organisations?
}

\section{William Budiselik $^{1, *}$, Frances Crawford ${ }^{2}$ and Donna Chung ${ }^{1}$}

1 School of Occupational Therapy and Social Work, Curtin University, Western Australia 6102, Australia; E-Mail: d.chung@curtin.edu.au

2 School of Health, University of New England, New South Wales 2351, Australia; E:Mail: f.crawford@une.edu.au

* Author to whom correspondence should be addressed; E-Mail: w.budiselik@curtin.edu.au; Tel.: +61-8-9266-7982; Fax: +61-8-9266-3636.

Received: 27 June 2014; in revised form: 28 August 2014 / Accepted: 2 September 2014 / Published: 16 September 2014

\begin{abstract}
On 12 November 2012 the then Australian Prime Minister Julia Gillard announced she was recommending to the Governor General the establishment of a Royal Commission into Institutional Responses to Child Sexual Abuse. Following inquiries in Australia and elsewhere much is already known about institutional and inter-institutional child protection failures and what is required to address them. That Australia's national government has pursued another abuse inquiry with terms of reference limited to institution-based (excluding the family) sexual abuse is of interest given the lack of political will to enact previous findings and recommendations. This article examines the background to the Government's announcement, the Commission's terms of reference and some of its settings, and literature on the nature of royal commissions across time and place. After the lack of success in implementing the recommendations of previous inquiries into how to better protect Australia's children, the question is: how will this Royal Commission contribute to Australian child protection and safety? Will the overwhelming public support generated by "truth speaking to power" in calling for this inquiry translate into action?
\end{abstract}

Keywords: child abuse; child sexual abuse; child protection; royal commissions; child protection inquiries; child safe organisations 


\section{Introduction}

The sexual abuse of children is widely regarded as one of the most morally unacceptable forms of (mainly male) adult human behaviour. The public “outings” of abusers over the past 20 or so years of those once regarded as pillars of the community_clergymen, police and judicial officers, entertainers, teachers, sporting coaches, youth workers and the like-took the public by surprise for two reasons: it contradicted community expectations about who it thought sexually abused children and the extent of the abuse. Due to victims and their supporters speaking out, increased research and professional interventions, and greater numbers of investigative journalists' media reports, the prevalence and nature of sexual abuse of children is now better understood but still shocking to the community [1]. In this article we critically examine the most recent response to child sexual abuse that is taking place involving Australian institutions. Acknowledging the importance of "truth speaking to power" in the activities leading to the government's decision to hold this royal commission, our examination is underpinned by a concern about the importance of implementing recommendations to bring about change along with redress for the past. The evidence is that knowledge generated through previous inquiries has failed to be translated into practice, often through a lack of political and populist commitment to the resourcing protecting children requires. In an era of user pays who are the users of protected children?

\section{The Australian Royal Commission into Institutional Responses to Child Sexual Abuse}

On 19 November 2012, a week after the Australian Prime Minister's announced intention to establish a Royal Commission into Institutional Responses to Child Sexual Abuse (the Commission), the Commission's secretariat released a consultation paper seeking input from interested individuals and organisations concerning "the arrangements for the establishment of the Royal Commission, including the scope ... the form ... the number and qualifications of Royal Commissioner/s and the reporting timetable" [2]. The response deadline of 26 November 2012 betrayed the pressure on those designing the Commission and preparing its budget. The Commission's terms of reference were presented on 15 January 2013 and Justice Peter McClellan from the New South Wales Supreme Court of Appeal was appointed the Commission's Chair.

The Commission's terms of reference require the royal commissioners to inquire into and report on: what institutions and governments should do to better protect children against child sexual abuse and related matters in institutional contexts in the future;

a what institutions and governments should do to achieve best practice in encouraging the reporting of, and responding to reports or information about, allegations, incidents or risks of child sexual abuse and related matters in institutional contexts;

b what should be done to eliminate or reduce impediments that currently exist for responding appropriately to child sexual abuse and related matters in institutional contexts, including addressing failures in, and impediments to, reporting, investigating and responding to allegations and incidents of abuse;

c what institutions and governments should do to address, or alleviate the impact of, past and future child sexual abuse and related matters in institutional contexts, including, in particular, in ensuring 
justice for victims through the provision of redress by institutions, processes for referral for investigation and prosecution and support services (emphases added) [3].

In our opinion, the time pressure on those designing the Commission was driven more by ephemeral political forces and less associated with the Australian Government's desire to establish a considered response to past abuse and to prevent it in the future. An appropriation of $\$ 434,000,000$ (US\$403,000,000) was granted for the Commission's operation. Other costs associated with agency effort (government and non-government) and securing professional advice and legal representation are not known, in part because non-government entities, such as the Catholic Church, are not obligated to advise its members or the public of such expenditure.

This considerable expenditure of money and human resources raises the question of whether these could have been better used to further a broad Australian child protection and abuse response agenda and services, rather than the re-examination of issues associated with past institution-based child sexual abuse. It remains to be seen whether the Commission is an opportunity lost or whether it delivers reforms commensurate with Australia's investment in it.

\section{What Led to the Establishment of the Commission?}

Events leading to the Australian Government's decision to establish the Commission are numerous and complex. There was both community organising and media campaigning to raise public consciousness of the issue. These were driven by continuing grass roots outrage at the sexual abuse of children and the treatment of the abused who complained as adults. In this complexity two champions stand out: Hetty Johnston and Joanne McCarthy. Johnston established Bravehearts in 1997 in Queensland as a community-based initiative to "educate, empower and protect Australian kids from sexual assault" and "move this once taboo subject into the light" [4]. In 2005 and 2012 Johnston was an author of papers, with Carol Ronken, about the need for a royal commission, refuting all arguments that had circulated against the idea [5,6]. McCarthy was recognized in 2013 with the top Australian journalism award for stories that helped spark the Commission [7]. Amplifying this groundwork was one specific catalyst for the Government's announcement: Detective Chief Inspector Peter Fox's open letter in the Newcastle Herald on 8 November 2012 to New South Wales' Premier Barry O'Farrell calling for a royal commission into the Catholic Church's cover-up of sexual abuse. Part of Fox's letter read:

I have seen the worst society can dredge up, particularly the evil of paedophilia within the Catholic Church... Many police are frustrated by this sinister behaviour... The whole system needs to be exposed; the clergy covering up these crimes must to be brought to justice and the network protecting paedophile priests dismantled. There should be no place for evil or its guardians to hide... Many priests don’t want a royal commission nor does the hierarchy of the church, but God knows we need one [8].

It seems Fox's status as a serving New South Wales' police officer warranted a response from the New South Wales Premier: "One cannot hear allegations from someone with the stature of Detective Chief Inspector Peter Fox and do nothing”. ([9], pp. 16, 684) On 9 November 2012 the then Premier O'Farrell announced his intention to establish the "Special Commission of Inquiry into matters relating to the Police investigation of certain child sexual abuse allegations in the Catholic Diocese of Maitland 
Newcastle” (the Special Commission). The Special Commission established on 21 November 2012 and headed by Margaret Cunneen SC had two terms of reference: to establish whether in relation to child sexual abuse the Catholic Church hindered or obstructed, failed to report or discouraged witnesses and the circumstances in which Fox was asked to cease investigating church-based sexual abuse in the Newcastle-Maitland region of New South Wales [10].

When Tony Jones, the Australian Broadcasting Commission's Lateline host, tested Fox about various claims, including that "the church covers up, silences victims, hinders police investigations, alerts offenders, destroys evidence and moves priests to protect the good name of the church", Fox replied:

Oh, not only do I have evidence, it's irrefutable... The greatest frustration is that there is so much power and organisation behind the scenes (emphasis added) that police don't have the powers to be able to go in and seize documents and have them disclose things to us [11].

Fox's letter to Premier O'Farrell is straightforward: The target the Catholic Church, not only child sex offenders in the Catholic Church who are abusing children, but the "organisation" that operates "behind the scenes" to protect them.

While Fox's letter was addressed to a state premier, and despite the national government's decision not to accede to earlier calls for a royal commission from victims and victims' advocacy groups [6], this call for a royal commission was taken up nationally. In the days following the release of his letter, a Fairfax Nielsen poll suggested that 95\% of Australians supported a royal commission (cited in [12], p. 8).

On 26 November 2012 at the conclusion of the consultation period Australia's then Attorney General, Nicola Roxon, advised:

The commission needs to focus on systemic issues of child sexual abuse to make sure that recommendations can be implemented in a timely manner. It is very clear that the community wants the commission and all governments across Australia to do everything we can to make sure what happened in the past is never allowed to happen again ([13], pp. 13, 146).

Relevantly, the consultation paper had noted:

While it is important that the Royal Commission form its own opinions and recommendations, there is a large body of work already on hand from recent inquiries. The Terms of Reference for the Commission can request that this work be taken into account, both to ensure that the relevant findings, recommendations and responses are considered as well as to ensure that survivors who have already shared their stories in these inquiries do not need to do so again if they do not want to [2].

The Commission's terms of reference accommodated this concern by including in its Letters Patent a direction for the Commission to take (or not take) action or consider.

the need to establish appropriate arrangements in relation to current and previous inquiries, in Australia and elsewhere, for evidence and information to be shared with you in ways consistent with relevant obligations so that the work of those inquiries, including, with any necessary consents, the testimony of witnesses, can be taken into account by you in a way 
that avoids unnecessary duplication, improves efficiency and avoids unnecessary trauma to witnesses [3].

\section{The Sexual Abuse of Children and Moral Panic}

A number of authors and media analysts have argued that moral panics about childhood sexual abuse in their most recent iteration during the past 20 or so years have been largely due to media reporting [14,15]. In contrast, professionals in this area of work suggest that it is not so much a moral panic but that the abuse is now spoken about and better understood even if still taboo. The moral panic which is induced around the sexual violation of children's bodies evokes a strong reaction by the public to which politicians need to be seen to be doing something-either stopping its occurrence in the future and/or supporting the seeking of justice for those abused and the punishment of its perpetrators. Responses have been largely in the areas of legal and policy changes including changes to processes for giving evidence and stricter gatekeeping of people working with children. Whilst these changes have been welcomed, there remains a community stigma associated with being a victim of such abuse or of being associated with or identified as a perpetrator of child sexual abuse [14]. Governments operate to stop and redress childhood sexual abuse within a highly sensitive political environment of hyper moral judgment about those committing the crimes and their representatives, alongside an equally worried public concerned with having legal systems so robust that nobody is ever accused of such abuse "unfairly" due to the highly stigmatized identity it represents. The nature of these criminal acts is such that they often occur without witnesses or other evidence and victims are intimidated into silence; therefore the capacity of legal system to deal with such crimes is particularly challenged. It is within this socio-political context that the current Australian inquiry is taking place.

\section{On the Nature of Royal Commissions}

The Australian Government's decision to initiate a royal commission symbolically signals the seriousness of the problem of children being sexually abused within institutions. Royal commissions are traditional in British Commonwealth countries as a well-endowed institution at arms-length from government, authorised to draft a plan to address for the long-term a publically problematic issue [16]. Australia has conducted 132 royal commissions since federation with more held at state level [17]. The literature from the United Kingdom (UK), Canada and New Zealand as well as Australia suggests royal commissions can serve many purposes and these are not always under the control of those commissioning them. Thomas and Field ([18], p. 14) analysed the 1991 UK Royal Commission on Criminal Justice. The authors describe this Royal Commission as an institution for crisis management in that "the terms of reference may be so written as to mute the debate by changing the focus of attention". They argue the UK government was able to prioritise the recommendations to suit their ideological agenda, ignoring the generating concern and ensuring "the parade of pluralist reasoned debate (was) replaced by the parade of ideological populism” ([18], p. 160).

In contrast, Inwood [16] argues that a royal commission can be a vehicle for a transformative moment in a nation. The focus of the Royal Commission analysed by Inwood was concerned with deciding the agenda for the Canadian political economy. This Royal Commission operated as a site for the rigorous and regulated interplay of ideas, institutions and interests. Research was open and transparent and 
included the active canvassing of submissions from the public. Inwood ([16], pp. 10-11) identifies three factors in the possibility of transformative moments arising out of royal commissions. The first lies in “political viability, economic viability and political and bureaucratic leadership". In the end decision makers need to be swayed to a course of action. The second revolves around the concept of credibility and leverage to action. "Who says something is sometimes more important than how many say it". The final factor shared by transformative royal commissions is that ensuing "policies must mobilise support from coalitions of actors upon whose support, electoral and financial, elected politicians depend”.

A process of collective learning through argument and persuasion is the description that Owens and Rayner [19] arrive at in analysing the UK continuing Royal Commission on Environmental Pollution. Started in the 1960s it operates as a knowledge broker in leveraging emerging research on environmental matters and removing difficult decisions for the state from the public arena. Such brokerage is always about the negotiation and performance of power in situ and in regard to the environment the credibility of scientific knowledge was an instrument to be wielded for change. The authors conclude:

"Knowledge always matters but has most effect when it is skilfully framed to resonate in the climate of the day, originates from or is mediated by a trusted source, and is deployed in a timely manner or persistently over time, until conditions converge into a situation ripe for change” ([19], p. 18).

In contrast, an analysis of the 2001 New Zealand Royal Commission into the Genetic Modification of Crops concludes that the language of science in an era of neoliberalism and marketisation can be used to silence active participation in democracy by citizens concerned as to the limits of scientific certainty ([20], p. 585). Goven [20] queries this Royal Commission’s suggestion that citizens interested in science should not express doubts unless they have evidence from appropriately funded and conducted research projects. The author argues that the Commission accepts "an idealised science innocent of power relations (and) the current role of commercial interests in research and development in the biosciences. In this way (idealised) science acts as a vector through which economic liberalism (or neoliberalism) trumps democracy”.

All of these analyses have potential relevance for the current Commission. Also relevant is a much earlier piece of work. Biskup [21] in his classic look at "The Royal Commission that never was" unveils some further dynamics as to the workings of royal commissions. The topic under consideration to be referred to a royal commission in 1938 was the relationship between the State of Western Australia and church missions. This focus emerged from considerable public and media concern in response to evidence of abuse on missions including the sexual abuse of children. In bringing the abuse to light a Minister in Western Australia's government stated at the time:

the natives [Aboriginal Australians] are first and foremost a charge upon the State, whoever may subsequently be delegated more directly to handle them, and our duty is to ensure that the job is efficiently undertaken by those best qualified to do so ([21], pp. 89-90).

This language captures a significant difference to current discourse in a marketised, privatised and commodified society where services are outsourced and a provider is responsible for meeting specified pre-determined quality standards. In 1938, alongside the discourse of state responsibility there was also a taken-for-granted acceptance of the vulnerability of Aboriginal people including their children. While 
the public expressed great concern at the stories of abuse in church-run missions, power was negotiated behind the scenes between the government and its departments, churches and pastoralist power holders. Despite many meetings and much media talk of calling a royal commission it never evolved. An editorial in The West Australian newspaper of 17 February 1939 commented after a large public conference on the issue: "It is good to see a number of people getting excited about the matter. The doubt is whether they got excited about the conditions of the (vulnerable) or about their own personal feelings" (cited in [21], p. 108).

This historical event can be viewed from this distance as necessarily steeped in colonialism, racism, religion and political ideology. At the time however there were concerned citizens able to name child sexual abuse and other forms of abuse. They proved not able to organise to move to action against those with investment in the status quo.

More recently an Inquiry (not a royal commission) for the Northern Territory Government documented extensive crimes of child sexual abuse in that jurisdiction [22]. This time there was a swift and organised response at the national level. Then Prime Minister John Howard used his federal powers to intervene in the governance of the Territory. As Fawcett and Hanlon [23] describe, the emotion of outrage at child sexual abuse was used to justify widespread intervention, much of which had neither direct link to established knowledge in child protection nor impact on the incidence of these crimes. Certainly the timing and nature of this intervention met few of the factors necessary for a transformative moment in addressing this problem. The lack of open collaboration in planning a response meant an ongoing lack of coordinated child protection in the Northern Territory.

Prasser identifies a changing pattern in the use and nature of Australian royal commissions since the 1970s [24]. This change has particularly been in the balance between inquisitorial forms investigating publically unacceptable incidents and issues, and advisory forms investigating major policy areas like health. There has been an increasing use of royal commissions to address what are perceived to be political and ideological issues but overall "Commonwealth Coalition governments have a lower rate of appointing royal commissions in relation to their length of time in office” ([24], p. 29). Certainly John Howard, a former Coalition Prime Minister, was clear in his rejection of a royal commission into child abuse in 2003 when he stated: "I would rather spend the \$60 million to \$100 million involved in a royal commission on further intervention (in child care) than I would on lining the pockets of lawyers” (cited in [24], p. 43). It is arguable that Howard acted on these beliefs when he commissioned the Northern Territory National Emergency Response in 2007 [23].

Independence is a valued characteristic of royal commissions but there is no certainty that the knowledge on an issue so generated will guide the actions of government. As Prasser notes, governments establish royal commissions for "politically expedient reasons such as to show concern about an issue, give an illusion of action, show responsiveness to a problem, co-opt critics, reduce opposition, delay decision-making and reassert control of the policy agenda” ([24], p. 34).

Royal commissions, as a means of identifying the extent, dynamics and effects of a problem, typically offer robust insights and recommendations, which are necessarily comprehensive, in order to address complex problems. The difficulty or often disappointment lies post-commission when recommendations are not acted on, not implemented as envisaged or a small number of recommendations are acted on which do not comprehensively remedy the problem into the future. The present Commission will report to an administration different from the one which appointed it. That there is a possible "disconnect" between 
the administration in power and the Commission is a further confounding factor in attempting to discern the Commission's likely efficacy. It makes for uncertainty both in terms of achieving redress for those bearing witness as to their abuse and for the major implementation of any changes designed to make children safer from child sexual abuse in the future.

\section{Current and Previous Inquiries}

It is beyond the scope of this article to comprehensively present the large number of relevant previous and current inquiries, and their recommendations germane to the current Commission. Consideration of all relevant inquiries is difficult because not all are reported publicly, and a national register of relevant inquiries into matters related to child protection and child abuse does not exist. Indeed, it is likely some are held as confidential documents in various organisations.

The Australian Institute of Family Studies provided to the Commission a list of 23 inquiries conducted in the last decade in Ireland, the United Kingdom, Canada and New Zealand excluding reviews and reports into individual deaths or government annual reports into child deaths [25]. The Australian Institute of Health and Welfare's (AIHW) 2011/2012 report into child protection provides a list of 16 Australian state and territory child protection inquiries conducted in the "past few years” ([26], p. 136).

Since the AIHW report provided its list of inquiries from the "past few years”, Victoria's "Betrayal of Trust: Inquiry into the handling of child abuse by religious and other non-government organizations" (Victorian Betrayal of Trust Inquiry) [27] has been completed and the New South Wales Special Commission [5] reported on 31 May 2014. In Western Australia in September 2012 a relevant inquiry report entitled “St Andrew's Hostel Katanning: How the system and society failed our children” [28] was provided to the Western Australian Parliament by a former president of the Western Australian Children's Court, Peter Blaxell.

In addition to these inquiries there are inquiries conducted by organisations themselves, for example, Olsson and Chung's "Report of the board of inquiry: Into the handling of claims of sexual abuse and misconduct within the Anglican diocese of Adelaide" [29] established by the Synod of the Diocese of Adelaide in 2003, and Parkinson, Oates and Jayakody's "Study of reported child sexual abuse in the Anglican Church” [30]. Commissioned by the Church’s Professional Standards Commission, this latter study aimed to examine abuse reports in the Australian Anglican church. The authors reported that while all 23 diocese were invited to participate in the research, three declined ([30], p. 13).

Last, given the focus of the current Commission is on past sexual abuse, earlier inquiries conducted at the time are relevant, as are Government and organisational responses to recommendations.

\section{Recommendations of Earlier Inquiries}

In 2009, a Senate Committee (the Committee) report entitled "Lost Innocents and Forgotten Australians Revisited” [31] examined the responses of Australia's governments (federal, state and territory) to two earlier federal government inquiries, one about child migrants [32] and the second about children who had experienced institutional or out-of-home care [33]. The Committee's conclusion on revisiting the impact of these inquiries was "the responses to the recommendations of earlier inquiries by the Commonwealth and State governments, the churches and agencies has been variable...in other areas progress is slow or no action has been taken” ([31], p. 6). 
In reviewing these earlier inquiries the Committee reconsidered the Forgotten Australians inquiry recommendation that the government consider initiating a "narrowly conceived" royal commission of "short duration" into state, charitable and church-run institutions and out-of-home care if within a period charitable and church-run institutions had failed to open their files and premises and provide full cooperation to authorities to investigate the nature and extent of criminal assault, sexual assault and report on past criminal practice and persons suspected of having committed crimes against children in care (emphases added) ([31], p. 65). Australia's federal and state governments did not favour this recommendation at that time ([31], p. 69).

In short, past inquiries have commonly found that there have been various forms of assault and abuse committed against children by those in positions of power over others. These forms of abuse involved organised groups of perpetrators in some organisations and in other areas there were instances of individuals using their position to assault and silence victims without the systematic involvement of others. Some key common issues stand out: those victims disclosing to authorities during or closely following the abuse were often not believed and their characters were often maligned leaving them in a worse position and the perpetrator without scrutiny. The reputation of the organisations and individuals involved often drove the apparent lack of response and disparagement of whistleblowers. Consequently, where allegations were made, organisational representatives did not consistently—or in some cases ever-refer the allegations to the police for investigation. Therefore many recommendations of past inquiries focused on the organisational cultures, values and lack of transparency that enabled these abusive situations to continue. Another aspect noted is the adversarial role of lawyers and their recommendations for organizational risk avoidance that served to dissuade organisational representatives speaking out about abusive or suspected abusive individuals and the organisation. Recommendations generally include changes to organisational practices to become more accountable and transparent within the organisation and in working with the relevant authorities when abuse is disclosed and to prevent future abuse.

In 2009 the Committee canvassed arguments for and against a royal commission and concluded against establishing one:

The Committee's conclusion was ultimately based on an assessment of the likely success of a Royal Commission in achieving successful exposure and prosecution of perpetrators of criminal acts. The Committee senses that there may be unrealistic expectations held by many as to the outcome of a Royal Commission. Despite the wider powers of royal commissions, the Committee considers that any such inquiry would face the same barriers to success as outlined above in relation to judicial inquiries, and accordingly would be unlikely to produce outcomes that would justify the significant expenditure of both time and finances ([31], p. 225).

The Committee then sensed there might be unrealistic expectations about the outcomes of such a royal commission. The current Commissioners are struggling to respond to the large number of people wishing to come forward and individually meet with them. By April 2014, Justice McClellan advised the community "the Commissioners have held 1426 private sessions... received 1328 written accounts from survivors or their family and friends...1065 people in the queue awaiting a session... receive about 40 requests for a private session each week". He estimated by the end of 2015 there may be 2000 people who will have requested a private session which could not be accommodated [34]. 
The Committee's consideration may have also been influenced by the reduction of the number of children in traditional forms of institutional/residential care: a social issue on a trajectory to fade with time.

The number of children in institutional/residential care has decreased markedly from approximately 27,000 in 1954 to less than 2000 currently. Most states and territories have phased out large institutions, with the majority of residential care now provided in small facilities caring for three to eight children. ([31], p. 62).

Today, in Australia, children in out-of-home care and other forms of care (e.g., day care) are cared for in ways not resembling the institutions that existed through to the last quarter of the twentieth century: "The majority of children (93\%) in out-of-home care at 30 June 2012 were in home-based care-44\% in foster care, $47 \%$ in relative/kinship care and $2 \%$ in other types of home-based care” ([25], p. 38). This raises the critical question of whether the resources could have been better used trying to implement past recommendations that have been consistently identified and partially implemented. The lack of thorough implementation can be attributed to a few factors including the obvious issue of financial cost, trying to engage and coordinate multiple jurisdictions and authorities, and a less tangible cultural aspect that child sexual abuse is still thought of by some as a rare occurrence not requiring this level of attention and investment.

\section{Systemic Failures and the Protection of Church Located Abusers}

The systemic problems in addressing church located child abuse have long been raised and reported in Australia. In the 1990s the New South Wales’ Royal Commission into the New South Wales Police Service (the Wood Royal Commission) [35] in part addressed the issue of child sexual abuse and Australian churches. Commissioner Justice James Wood identified the problem as the substantial incidence of sexual abuse involving those associated with churches. He wrote that the failure to properly investigate allegations or pursue allegations through the courts was "suggestive of either protection or failure on the part of the official agencies involved to exercise their powers impartially" ([35], p. 991). Fox's assertion in November 2012, that "power and organisation behind the (Church) scenes” blocks effective action, is consistent with Wood's earlier assessment.

\section{Working with Children Checks}

In light of the Wood Royal Commission, Australia's (state and territory) community services ministers agreed to implement safety screening of persons employed in a paid or voluntary capacity in services for children. Characteristic of Australian federalism, each state and territory has, since Wood's report, developed different legislation, procedures and requirements to screen its working with children workforce ([36], p. 350).

Australia's peak intergovernmental forum, the Council of Australian Governments (COAG), promotes reforms of national significance and those requiring inter-jurisdictional coordination. In April 2009 COAG released its "National Framework for Protecting Australia’s Children 2009-2020” (the national framework) [37]. The national framework announced that all Australian governments had endorsed a long-term approach to child protection. The national framework report emphasised a shift towards a "public health” model of child protection ([37], p. 6). Stated aims of the national framework 
included developing a "nationally consistent approach to working with children checks and child safe organisations across jurisdictions” ([37], p. 14).

In 2011, an update was provided by the state and territory officers responsible for achieving "a nationally consistent approach” to working with children checks:

Harmonisation of state and territory legislation would require substantial investment of resources to bring the data and related information management mechanisms into line. Current fiscal constraints make additional financial commitments untenable as part of an agile response (emphasis added). There is insufficient evidence to inform a best practice screening model [38].

Australian states and territories do not have a common child workforce checking process. State and territory child protection authorities do not have mechanisms in place to systematically exchange information about persons believed responsible for child abuse. That Australia does not have a national approach to screening its working with children workforce seems in part to be the result of "fiscal constraints". At the present time there is no indication of any future commitment to such national efforts.

\section{The Australian Catholic Church, Cardinal Pell and the Ellis Defence}

In response to demands for inquiries and commissions into the Catholic Church, its most senior Australian representative, Cardinal George Pell, positioned the Catholic Church in the following way:

If there was need for another general inquiry it should be wide ranging, covering not only the Catholic Church but all religions and charities, and not only non-government organisations but government organisations also. I cannot see the need for a state-wide Royal Commission at this time but if there was one the Catholic Church authorities would cooperate fully [39].

Pell's testimony to the Commission has been widely reported in the Australian press. Part of Pell's testimony and that which is most widely reported related to a 2007 case, Trustees of the Roman Catholic Church v Ellis \& Anor (2007) NSWCA 117 (the Ellis case) and the Church's use of the so called "Ellis defence”, which the authors understand to mean the Catholic Church is not liable for the criminal activity of its clergy. This is largely a legalistic argument by the Catholic Church not to take responsibility for abuse by its clergy. It was viewed publicly as yet another example of an abuse victim seeking justice and being denied it by the Church.

Victoria's Betrayal of Trust inquiry report dealt with the issues raised in the Ellis case in the following terms:

The Committee recommends that the Victorian Government consider requiring organisations it funds or provides with tax exemptions and other entitlements to be incorporated and adequately insured. It also suggests that the Victorian Government work with the Australian Government to require religious and other non-government organisations that engage with children to adopt incorporated legal structures. ([27], p. xxxix). 


\section{Child Safe Institutions: A Worthy Aspiration for ever Vigilant Organisations}

The current Commission's activities are broadly delimited by the meanings of the word institution and the phrase institutional context. In the child welfare literature “institutional abuse”, a phrase used since the early 1980s, is much broader than sexual abuse and those behaviours related to it. For example, Gil defines institutional child abuse as when a system is "detrimental to a child's health, safety, or emotional and physical well-being or in any way exploits or violates a child's basic rights” [40].

“Institution” and “institutional context” are defined in the Commission’s Letters Patent [3]:

(institution) means any public or private body, agency, association, club, institution, organisation or other entity or group of entities of any kind (whether incorporated or unincorporated), and however described, and:

i. includes, for example, an entity or group of entities (including an entity or group of entities that no longer exists) that provides, or has at any time provided, activities, facilities, programs or services of any kind that provide the means through which adults have contact with children, including through their families; and

ii. does not include the family.

institutional context: child sexual abuse happens in an institutional context if, for example:

a. it happens on premises of an institution, where activities of an institution take place, or in connection with the activities of an institution; or

b. it is engaged in by an official of an institution in circumstances (including circumstances involving settings not directly controlled by the institution) where you consider that the institution has, or its activities have, created, facilitated, increased, or in any way contributed to, (whether by act or omission) the risk of child sexual abuse or the circumstances or conditions giving rise to that risk; or

c. it happens in any other circumstances where you consider that an institution is, or should be treated as being, responsible for adults having contact with children.

The Commission's issue paper "Child Safe Institutions" uses interchangeably the phrase "child safe institutions" and "child safe organizations”, while emphasising it is concerned about child sexual abuse in an institutional context.

In this paper, the first question posed by the Commission assumes the possibility of creating a "child safe organisation":

Of particular interest to the Royal Commission is:

The essential elements of establishing a "child safe organization” that protects children from sexual abuse in an institutional context. In particular, are there core strategies that should be present and others that are less critical?

The question is premised on a (comforting) belief that a child safe organisation is achievable rather than aspirational. To reinforce the Commission's presumption and to assist those making submissions, a number of resources are provided that set out various child safe frameworks and checklists. Unfortunately, this certainty of child safe organisations cannot be guaranteed to be attained and 
maintained. Organisations can be more or less safe and unsafe. Organisations that are safer have mechanisms to demonstrate how they are not "unsafe" and provide avenues to facilitate the reporting and addressing of anything that is unsafe. At its most cynical, working towards a child safe organisation can be a risk management strategy to protect the organisation and its workers by denying children the opportunity for development associated with manageable risk.

That a child safe organisation is an aspiration that is not achievable might seem to some a trite distinction. Arguably, it is an important distinction to those shaping the Australian community's response to these issues. To offer solace to parents and others interested in child welfare by encouraging a belief that an organisation is capable of being made safe is to suggest certainty is possible. Rather, this territory requires their constant vigilance and their acceptance of limits to certainty as to what is happening to children. The private nature of much abuse perpetrated and the silencing tactics of abusers means there will not be "full information" available. Use of the term "best practice” in the Commission's terms of reference works to silence concerns about uncertainty by suggesting that knowledge to control the incidence of child sexual abuse in institutional care exists and is both identifiable and applicable. It promotes the perception that continuing risks to children are measurable and manageable through instruments such as insurance.

Consider the National Disability Service's response to the issues raised by the Commission in respect of services to children with disability:

(In some cases) providers have unique access to people's home environments... Out-of-home care (including respite) is a high-risk category. Children in these services may have heightened vulnerability due to factors such as childhood trauma, estrangement from family and instability associated with multiple placements. They are also exposed to situational risk factors associated with extensive periods of unsupervised one-on-one contact with a staff member, or they may be living with other children with the potential to cause harm to them [41].

\section{Breaking the Cycle: Well-Funded Inquiries Alongside Poorly Resourced Services}

The federal government's assertion that systemic institutionally located abuse is able to be eliminated given sufficient funding is tantalising. In February 2013, the then Attorney-General Mark Dreyfus assured the Australian community that: "our government is going to do everything it can to make sure that what has happened to children in the past is never allowed to happen again...since its very inception we have made clear to the royal commission and we make it clear to the Australian community that this government is determined to ensure the royal commission is adequately resourced" [42]. The Commission's funding enables it to provide appropriately trained staff and support to victims coming forward. For example, Justice McLellan's description of the sensitive way in which people coming forward to the Commission are received describes a level of resourcing not available to services which have attempted to provide responses to past abuse victims: "We have been careful to employ appropriately trained people to answer the telephone when the initial contact is made and we have in place professional counsellors to assist people who come to a session. Recognising that many people will experience a decline in mood following their session we are careful to follow people up to ensure they have adequate support available” [34]. 
The promise that the Commission can wrestle with sexual abuse and create environments which are safe might be viewed in the context of a statement made in the Victorian Parliament in March 2014 (noting the Victorian Betrayal of Trust inquiry report [27] was delivered in November 2013 and the Commission commenced in January 2013):

Victoria needs an open, properly resourced inquiry into the allegations that vulnerable children in the care of the state have been groomed and exploited for criminal sexual abuse. The Napthine government will fail its duty of care if it refuses to immediately launch an inquiry into such systemic failures. The inquiry should run in tandem with police investigations into specific offences. This model of coordinated investigations into child sexual abuse was efficient and effective in revealing systemic failures by religious and other non-government organisations.

The government should stop resisting such an inquiry following today's admission by the principal commissioner of the Commission for Children and Young People, Bernie Geary, that the system is "shabby". He also disclosed he was unsurprised by reports that up to 40 children as young as 12 were being exploited while in the care of the state. This is an indictment of the system which must be exposed and fixed as a matter of the utmost urgency ([43], p. 623)

The Youth Affairs Council of Victoria released a statement welcoming the announcement of an inquiry by the Victorian Commissioner for Children and Young People, which advised that the inquiry would look at the sexual exploitation and assaults of children in care by outsiders, and sexual violence committed by other children in care. The statement read: "it (the inquiry) also responds to concerns about vulnerable and traumatized young people being housed in settings which are understaffed and underfunded (emphasis added)” [44].

\section{Conclusions}

On 23 July 2014 the South Australian premier, Jay Weatherill, made a statement to that State's parliament advising it that if allegations under police investigation about child abuse of children in the state's residential care facilities by a Families $S A$ employee were proven true, he would initiate a royal commission into them. The details of the allegations are apparently so appalling that the premier is not ruling out barring males from caring positions within the department. Ironically, in South Australia Families SA administers paragraph 8A(h)(i) of the Child Protection Act 1993 (SA), which requires it "to monitor progress towards child safe environments in the government and non-government sectors and to report regularly to the Minister on that subject”.

With respect to the Commission, Weatherill said: "I think it is also probably worth mentioning at this juncture that there is an existing royal commission into child sexual abuse which is currently on foot at the federal level. It is more likely than not that this matter could be the subject of interest by that royal commission, but it may well also be the case that there would be a separate need for South Australia to have its own inquiry, having regard to the needs of its own system.” [45].

As discussed there are various reasons contributing to the implementation gap concerning the take-up of child protection recommendations by governments. Additionally, in Australia a structural 
impediment exists: its federal system of government. While there are national policy and decision making forums such as the Coalition of Australian Governments and various ministerial councils, representing national and state and territory interests, and these have considered issues and developed plans for children's safety, on a constitutional and operational level, state and territory governments are responsible for child protection. So, in the case of the Commission, we have a national government that will receive recommendations with state and territory governments not having an obligation (or in the absence of the national government's support, possibly the financial resources) to implement them. Therefore at this time there is no obvious "fit" between the national government's recommendations, and responsibility and funding for their implementation. Without such a fit, the main incentive for states and territories may be the moral imperative of their desire to improve the safety of children in out-of-home forms of care (and associated programs). Because of its terms of reference the Commission will not address how to better prevent child sexual abuse occurring within family, which is a major area of state and territory child protection responsibility. In this respect, the Commission's limited focus can send the message that governments are less concerned to stop family-based sexual abuse.

It seems inevitable, in keeping with a culture of forgetting about previous inquiries, that even before the Commission has concluded its hearings and prepared its recommendations, Australia's Governments will have commissioned further inquiries and more recommendations will be generated. How will the findings of the present Commission impact the future in keeping children safe from child abuse?

There is plenty of existing evidence as to what factors need to be addressed in providing for children's wellbeing and what impact child abuse has on individual development. At the same time there is also longstanding evidence that the resources required to adequately implement this knowledge are beyond what is considered politically feasible to governments of all political persuasions. Child sexual abuse and related acts are committed by those who rest assured that children's vulnerability will not be protected by vigilance. Will a focus on the language of legal redress cover all that is required in the everyday practices of making organisations safer for children?

It is a value-based principle that the sexual abuse of children is abhorrent and to be prevented. In an era of economic rationalism there could be a case made for the economic benefit of organisations investing in child protective practices so as not to have to pay redress to those abused and to prevent the impairment of trauma on future workers. In leveraging the political capital to bring about the Commission it would seem values rather than the market forces shaped the outcome of calling a royal commission. Hetty Johnston and Joanne McCarthy were among many Australians embodying the age-old principle of "truth speaking to power". The past history of royal commissions suggests that success in calling a royal commission does not guarantee any control over the outcome. To this end in the case of this Commission, is it possible to "mobilise support from coalitions of actors upon whose support, electoral and financial, elected politicians depend?” ([16], p. 9).

Julia Gillard, at her final press conference as Prime Minister, after being initially reluctant to call the Commission, took the opportunity to predict the outcome: "This royal commission is now working its way around the country. I believe it will have many years of work in front of it. But it will change the nation.” (cited in [12], p. 8). Only the future will determine her prescience on this matter. 
This article concludes by posing a question directed toward Australia's decision makers (be they citizens, politicians, professionals and/or policy makers): How can better outcomes be achieved from the effort put into inquiries? The Commissioner has been authorized to draft a plan to address for the long-term the publically problematic issue of sexual abuse of children in institutional contexts. Knowing what has happened to the recommendations of previous inquiries into child abuse, how can such a plan address the issue of implementation of recommendations from this inquiry?

\section{Acknowledgments}

Thanks to three anonymous reviewers for their valuable comments on an earlier draft.

\section{Author Contributions}

Budiselik initiated the writing process, produced early drafts and synthesized authors' contributions; Crawford reviewed and revised the article, contributed to its structure and reviewed the literature on royal commissions; Chung reviewed and revised the article, contributed to the theoretical approaches used, and its structure and argument.

\section{Conflicts of Interest}

The authors declare no conflict of interest.

\section{References}

1. John Pratt. "Child sexual abuse: Purity and danger in an age of anxiety.” Crime, Law and Social Change 43 (2005): 263-87.

2. Secretariat, Royal Commission into Child Sexual Abuse. "Consultation Paper on the Establishment of the Royal Commission into Institutional Responses to Child Sexual Abuse”. 2012. Available online: http://parlinfo.aph.gov.au/parlInfo/download/media/pressrel/2056920/upload_binary/2056 920.pdf;fileType=application/pdf (accessed on 18 June 2014).

3. Australian Government ComLaw. "Letters Patent for the Royal Commission into Institutional Responses to Child Sexual Abuse.” Available online: http:/www.comlaw.gov.au/Details/ C2013G00083 (accessed on 26 July 2014).

4. Bravehearts. "Bravehearts' Key Purpose Is to Educate, Empower and Protect Australian Kids from Sexual Assault.” Available online: http://www.bravehearts.org.au/pages/about-us.php (accessed on 15 August 2014).

5. Hetty Johnston, and Carol Ronken. "Position Paper: The Need for a Royal Commission into the Sexual Assault of Children in Australia.” 2005. Available online: http://www.bravehearts.org.au/ files/pos_paper_royal_commission.pdf (accessed on 26 July 2014).

6. Hetty Johnston, and Carol Ronken. "Position Paper: The need for a royal commission of inquiry into the sexual assault of children in Australia.” 2012. Available online: http://www.bravehearts.org.au/ files/Royal\%20Commission_2012.pdf (accessed on 15 August 2014). 
7. Lucy Carroll. “Reluctant Reporter Wins Nation’s Top Journalism Prize the Sydney Morning Herald.” Available online: http:/www.smh.com.au/national/reluctant-reporter-wins-nations-topjournalism-prize-20131129-2yh34.html (accessed on 15 August 2014).

8. Peter Fox. "Don't block your ears to abuse Mr Premier." Newcastle Herald, 8 November 2012. Available online: http://www.theherald.com.au/story/757111/opinion-dont-block-your-earsto-abuse-mr-premier/?cs=308 (accessed on 26 July 2014).

9. Barry O’Farrell, and Garry Edwards. “Hunter Child Sexual Abuse Allegations.” Available online: http://www.parliament.nsw.gov.au/prod/parlment/hansart.nsf/0/16610DA0B94C902FCA257AC5 00118262 (accessed on 26 July 2014).

10. State of New South Wales. "Special Commission of Inquiry into Matters Relating to the Police Investigation of Certain Child Sexual Abuse Allegations in the Catholic Diocese of MaitlandNewcastle.” Available online: http://www.lawlink.nsw.gov.au/lawlink/Special_Projects/ll_ splprojects.nsf/vwFiles/Updated_Terms_of_Reference_12_February_2014.pdf/\$file/Updated_Te rms_of_Reference_-_12_February_2014.pdf (accessed on 26 July 2014).

11. Tony Jones. "Lateline Studio Interview with Peter Fox.” Available online: http://www.abc.net. au/news/2014-05-30/lateline-studio-interview-with-peter-fox/5490908 (accessed on 26 July 2014).

12. David Marr. The Prince: Faith, Abuse and George Pell. Australia: Black Inc. Publishing, 2013.

13. Nicola Roxon. "Royal Commission into Child Sexual Abuse.” Available online: http://parlinfo. aph.gov.au/parlInfo/search/display/display.w3p;query=Id\%3A\%22chamber\%2Fhansardr\%2Fc94 905e2-4370-462f-b408-d06e0d0a5c8e\%2F0143\%22 (accessed on 26 July 2014).

14. Philip Jenkins. Moral Panic: Changing Concepts of the child Molester in Modern America. New Haven: Yale University Press, 2008.

15. Kathryn J. Fox. "Incurable Sex Offenders, Lousy Judges \& The Media: Moral Panic Sustenance in the Age of New Media.” American Journal of Criminal Justice 38 (2013): 160-81.

16. Gregory J. Inwood. Continentalizing Canada: The Politics and Legacy of the Macdonald Royal Commission. Toronto: University of Toronto Press, 2005, vol. 21.

17. Parliament of Australia. "Royal Commissions and Commissions of Inquiry.” Available online: http://www.aph.gov.au/About_Parliament/Parliamentary_Departments/Parliamentary_Library/Br owse_by_Topic/law/royalcommissions (accessed on 26 July 2014).

18. Steward Field, and Philip A. Thomas. "Introduction: Justice and Efficiency? The Royal Commission on Criminal Justice.” Journal of Law and Society 21 (1994): 1-19.

19. Susan Owens, and Tim Rayner. "When knowledge matters: The role and influence of the Royal Commission on Environmental Pollution.” Journal of Environmental Policy \& Planning 1 (1999): 7-24.

20. Joanna Goven. "Processes of Inclusion, Cultures of Calculation, Structures of Power Scientific Citizenship and the Royal Commission on Genetic Modification.” Science, Technology \& Human Values 31 (2006): 565-98.

21. Peter Biskup. "The royal commission that never was: A chapter in Government-Missions relations in Western Australia.” University Studies in History 5 (1967): 89-113

22. Rex Wild, and Pat Anderson. "Ampe Akelyernemane Meke Mekarle 'Little Children are Sacred': Report of the Northern Territory Board of Inquiry into the Protection of Aboriginal Children from 
Sexual Abuse 2007." Department of the Chief Minister, 2007. Available online: http://www.inquirysaac.nt.gov.au/pdf/bipacsa_final_report.pdf (accessed on 26 July 2014).

23. Barbara Fawcett, and Maurice Hanlon. "Child sexual abuse and Aboriginal communities in Australia: A case study of non-inclusive government intervention.” European Journal of Social Work 12 (2009): 87-100.

24. Scott Prasser. "Royal Commissions in Australia: When should governments appoint them?" Australian Journal of Public Administration 65 (2006):28-47.

25. Australian Institute of Family Studies. "Institutional child sexual abuse inquiries 2002-2013.” Available online: http://www.aifs.gov.au/institute/pubs/carc/4.html (accessed on 26 July 2014).

26. Australian Institute of Health and Welfare. “Child protection in Australia 2011-2012.” Available online: http://www.aihw.gov.au/WorkArea/DownloadAsset.aspx?id=60129542752 (accessed on 26 July 2014).

27. Family and Community Development Committee. "Inquiry into the Handling of Child Abuse by Religious and other Organisations.” Available online: http://www.parliament.vic.gov.au/fcdc/ article/1788 (accessed on 26 July 2014).

28. Peter Blaxell. "St Andrews Hostel Inquiry: How the system and society failed our children." Available online: http://www.publicsector.wa.gov.au/document/st-andrew\%E2\%80\%99s-hostelkatanning-how-system-and-society-failed-our-children (accessed on 26 July 2014).

29. Leslie T. Olsson, and Donna Chung. "Report of the Board of Inquiry into the Handling of Claims of Sexual Abuse and Misconduct within the Anglican Diocese of Adelaide.” Anglican Church of Australia, Diocese of Adelaide, 2004. Available online: http://www.adelaide.anglican.com.au/ assets/Uploads/Reports-and-Publications/14-24504finalboireportfinal.pdf (accessed on 26 July 2014).

30. Patrick Parkinson, Kim Oates, and Amanda Jayakody. "Study of reported child sexual abuse in the Anglican Church.” Available online: http://www.adelaide.anglican.com.au/assets/Uploads/ Reports-and Publications/07-Study-of Reported-Child-Sexual-Abuse-in-the-Anglican-Church2009.pdf (accessed on 26 July 2014).

31. Australian Senate Community Affairs Committee. "Lost Innocents and Forgotten Australians Revisited: Report on the Progress with the Implementation of the Recommendations of the Lost Innocents and Forgotten Australians Reports.” Available online: http://www.aph.gov.au/ / media/wopapub/senate/committee/clac_ctte/completed_inquiries/2008_10/recs_lost_innocents_fo rgotten_aust_rpts/report/report_pdf.ashx (accessed on 26 July 2014).

32. Australian Senate Community Affairs Committee. "Lost Innocents: Righting the Record on Child Migration.” Available online: http://www.aph.gov.au/ /media/wopapub/senate/committee/clac_ ctte/completed_inquiries/1999_02/child_migrat/report/report_pdf.ashx (accessed on 26 July 2014).

33. Australian Senate Community Affairs Committee. "Forgotten Australians: A Report on Australians Who Experienced Institutional or Out-of-home Care as Children.” Available online: http://www. aph.gov.au/ /media/wopapub/senate/committee/clac_ctte/completed_inquiries/2004_07/inst_care/ report/report_pdf.ashx (accessed on 26 July 2014).

34. Peter McClellan. "2014 Families Australia Oration.” Available online: http://www.childabuser oyalcommission.gov.au/media-centre/speeches/2014-families-australia-oration (accessed on 26 July 2014).

35. James Wood. "Royal Commission into the New South Wales Police Service-Final Report Volume IV: Paedophile Inquiry.” 1997. Available online: http://www.pic.nsw.gov.au/files/reports/RCPS\% 20Report\%20Volume\%204.pdf (accessed on 26 July 2014). 
36. William Budiselik, Frances Crawford, and Joan Squelch. "The Limits of Working with Children Cards in Protecting Children.” Australian Social Work 62 (2009): 339-52.

37. Council of Australian Governments. "Protecting Children is Everyone's Business: National Framework for Protecting Australia’s Children 2009-2020.” Available online: http://www.dss. gov.au/sites/default/files/documents/child_protection_framework.pdf (accessed on 26 July 2014).

38. Australian Government Department of Social Services. "Position Paper: Toward a Nationally Consistent Approach to Working with Children Checks.” Available online: http://www.dss. gov.au/our-responsibilities/families-and-children/publications-articles/a-nationally-consistentapproach-to-working-with-children-checks-2011 (accessed on 26 July 2014).

39. The Catholic Communities of St Mary Magdalene, Rose Bay St Therese, Dover Heights. “Statement from Cardinal George Pell.” 4 and 5 August 2012. Available online: http://www. rosebaydoverheightscatholics.com.au/wp-content/uploads/2012/08/Bulletin-4th-5th-August2012.pdf (accessed on 26 July 2014).

40. Eliana Gil. "Institutional Abuse of Children in Out-of-home Care." Child and Youth Services 4 (1982): 7-13.

41. National Disability Service. "Child Safe Institutions (submission to the Royal Commission into Institutional Responses to Child Sexual Abuse).” Available online: http://www.childabuseroyal commission.gov.au/getattachment/d26219d7-cfdf-493b-b4f4-e567426c09b4/33-NationalDisability-Services (accessed on 26 July 2014).

42. Mark Dreyfus. "Royal Commissions Amendment Bill 2013 Second Reading Speech.” Available online: http://parlinfo.aph.gov.au/parlInfo/genpdf/chamber/hansardr/e1b9741b-6117-42e6-bb54 219d93714fe7/0013/hansard_frag.pdf;fileType=application\%2Fpdf (accessed on 26 July 2014).

43. Frank McGuire. “Child Protection.” Available online: http://tex.parliament.vic.gov.au/bin/ texhtmlt?form=jVicHansard.one\&house=ASSEMBLY\%0A\&pageno=623\&date1=12\&date2=Ma rch\&date3=2014\&speech=124\&title=Child + protection $\% 0 \mathrm{~A} \& \mathrm{db}=$ hansard91\&query $=($ accessed on 26 July 2014).

44. Youth Affairs Council of Victoria. “'Inquiry Into Sexual Abuse In State Care Shows The Value Of Having An Independent 'Watchdog'.” Available online: http://www.yacvic.org.au/news/mediareleases/477-media-release-inquiry-into-sexual-abuse-in-state-care-shows-the-value-of-having-anindependent-watchdog (accessed on 26 July 2014).

45. Jay Weatherill. “Child Protection.” Available online: https://hansardpublic.parliament.sa.gov.au/ Pages/HansardResult.aspx\#/docid/HANSARD-11-16992 (accessed 28 July 2014).

(C) 2014 by the authors; licensee MDPI, Basel, Switzerland. This article is an open access article distributed under the terms and conditions of the Creative Commons Attribution license (http://creativecommons.org/licenses/by/3.0/). 